\title{
Morphological description of Isospora alyousifi nom.n. for I. acanthodactyli Alyousif et Al-Shawa, 1997 (Apicomplexa: Eimeriidae) infecting Acanthodactylus schmidti (Sauria: Lacertidae) in Saudi Arabia
}

\author{
Abdel-Azeem S. Abdel-Baki ${ }^{1,2}$, Heba M. Abdel-Haleem ${ }^{2}$ and Saleh Al-Quraishy ${ }^{1}$ \\ ${ }^{1}$ Zoology Department, College of Science, King Saud University, Saudi Arabia, P.O. Box 2455, Riyadh 11451, Saudi Arabia; \\ ${ }^{2}$ Zoology Department, Faculty of Science, Beni-Suef University, Egypt
}

\begin{abstract}
To date, three species of Isospora Schneider, 1881 have been described from lizards of the genus Acanthodactylus Wiegmann. Two of these, although representing separate species parasitizing two different hosts, Acanthodactylus boskianus Daudin in Egypt and A. schmidti Haas in Saudi Arabia, were described under the name Isospora acanthodactyli. The third species is Isospora abdallahi Modrý, Koudela et Šlapeta, 1998 from A. boskianus in Egypt. In the present study, Isospora alyousifi nom. n. is proposed to accommodate Isospora acanthodactyli Alyousif et Al-Shawa, 1997 (homonym of I. acanthodactyli Sakran, Fayed, El-Toukhy et Abdel-Gawad, 1994) and its redescription based on newly collected material is provided.
\end{abstract}

Keywords: homonymy, redescription, oocysts, endogenous stages, coccidia, sandy fringed-toed lizard, Riyadh

Lacertid lizards of the genus Acanthodactylus Wiegmann are widely distributed from West Africa to the Middle East (Harris and Arnold 2000, Harris et al. 2003, Rifai et al. 2003). Apicomplexan parasites of the genus Isospora Schneider, 1881 were first reported from lacertid lizards of the genus Acanthodactylus by Sakran et al. (1994), who described Isospora acanthodactyli from Acanthodactylus boskianus Daudin in Egypt. A few years later, Alyousif and Al-Shawa (1997), apparently unaware of the publication of Sakran et al. (1994), proposed I. acanthodactyli as a new species from $A$. schmidti from Saudi Arabia. The latter species thus became a homonym of $I$. acanthodactyli Sakran, Fayed, El-Toukhy et Abdel-Gawad, 1994. Meanwhile, Modrý et al. (1998) described another species, named by them as I. abdallahi, from A. boskianus from Egypt. Herein, we propose Isospora alyousifi nom. n. for Isospora acanthodactyli Alyousif et Al-Shawa, 1997.

\section{MATERIALS AND METHODS}

During a survey of coccidian parasites of lizards in the central region of Saudi Arabia, 40 adult sandy fringed-toed lizards, Acanthodactylus schmidti Haas, were collected by hand in the Thomama area $\left(24^{\circ} 41^{\prime} \mathrm{N}, 46^{\circ} 42^{\prime} \mathrm{E}\right)$ in Riyadh City during November 2011. In the laboratory, the lizards were housed individually in small plastic cages. Individual faecal samples were collected daily from the ground of the cages and subjected to routine faecal examination using Sheather's sugar floatation method (Levine 1973). Faecal materials of infected lizards were then suspended in $2.5 \%$ potassium dichromate solution, incubated at $25 \pm 1{ }^{\circ} \mathrm{C}$ and observed periodically to establish the sporu- lation time. Oocysts, sporocysts, sporozoites and other structures were measured and photographed using a calibrated ocular micrometer on an Olympus BX51 microscope with an Olympus DP71 camera. A total of 50 sporulated oocysts were measured. The measurements of the oocysts and the endogenous stages (in micrometres) are provided as arithmetic mean \pm standard deviation, with range in parentheses, together with the shape index (ratio of length/width). For histological examination, parts of the infected intestine were fixed in $10 \%$ neutral buffered formalin and embedded in paraffin. Serial sections were stained with haematoxylin and eosin.

\section{RESULTS}

Of the 40 adult sandy fringed-toed lizards Acanthodactylus schmidti examined in this study, eight shed oocysts in their faeces. Initially, the examined faeces contained nonsporulated oocysts, oocysts in the early stages of sporulation and a few fully sporulated oocysts. The majority of recovered oocysts became fully sporulated within 12 hours at $25 \pm 1{ }^{\circ} \mathrm{C}$ when placed in $2.5 \%(\mathrm{w} / \mathrm{v})$ aqueous potassium dichromate solution. The sporulated oocysts from all the examined lizards were found to belong to the genus Isospora and appeared to be of the same species. Below we present a morphological description of the oocysts and endogenous stages of this coccidian, which is considered conspecific with Isospora acanthodactyli Alyousif et Al-Shawa, 1997, which is a homonym of I. acanthodactyli Sakran, Fayed, El-Toukhy et Abdel-Gawad, 1994. To avoid this homonymy, a new name, I. alyousifi, is proposed and the species is redescribed on the basis of new material. 


\section{Isospora alyousifi nom. n.}

Figs. 1-16

Oocysts. Oocysts spherical to subspherical, $24.5 \pm 2.5$ $(17-29) \times 21 \pm 2.5(16-26)$, with length/width ratio of 1.11 (1.06-1.2) (Figs. 1-8, 16). Oocyst wall yellow, smooth, bilayered, $1.5(1.2-1.6)$ thick, composed of thicker outer layer (about two thirds of total thickness - Fig. 2) and smooth inner layer (about one third of total thickness - Fig. 6). Micropyle, oocyst residuum and polar granules absent. Sporocysts ovoidal, $13.5 \pm 1.5(8-16) \times 9 \pm 1.5(6-11)$, with smooth, singlelayered wall, 0.5 thick; length/width ratio of 1.4 (1.1-1.7) (Fig. 8). Stieda body (Fig. 1) as well as sporocyst residuum present; residuum composed of numerous granules of nearly same size (Fig. 5). Sporozoites elongate with spherical anterior and posterior refractile bodies (Fig. 7).
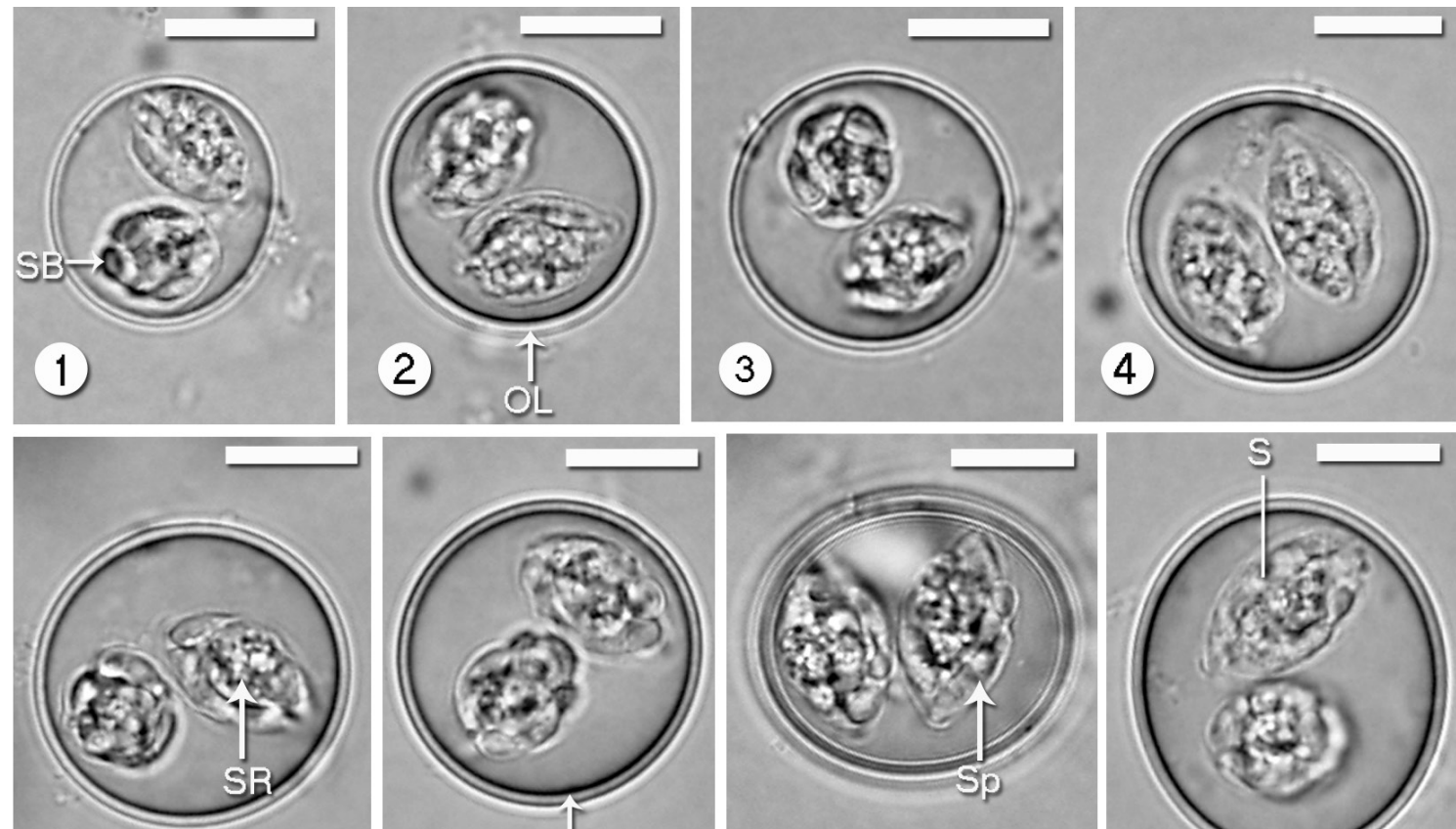

5
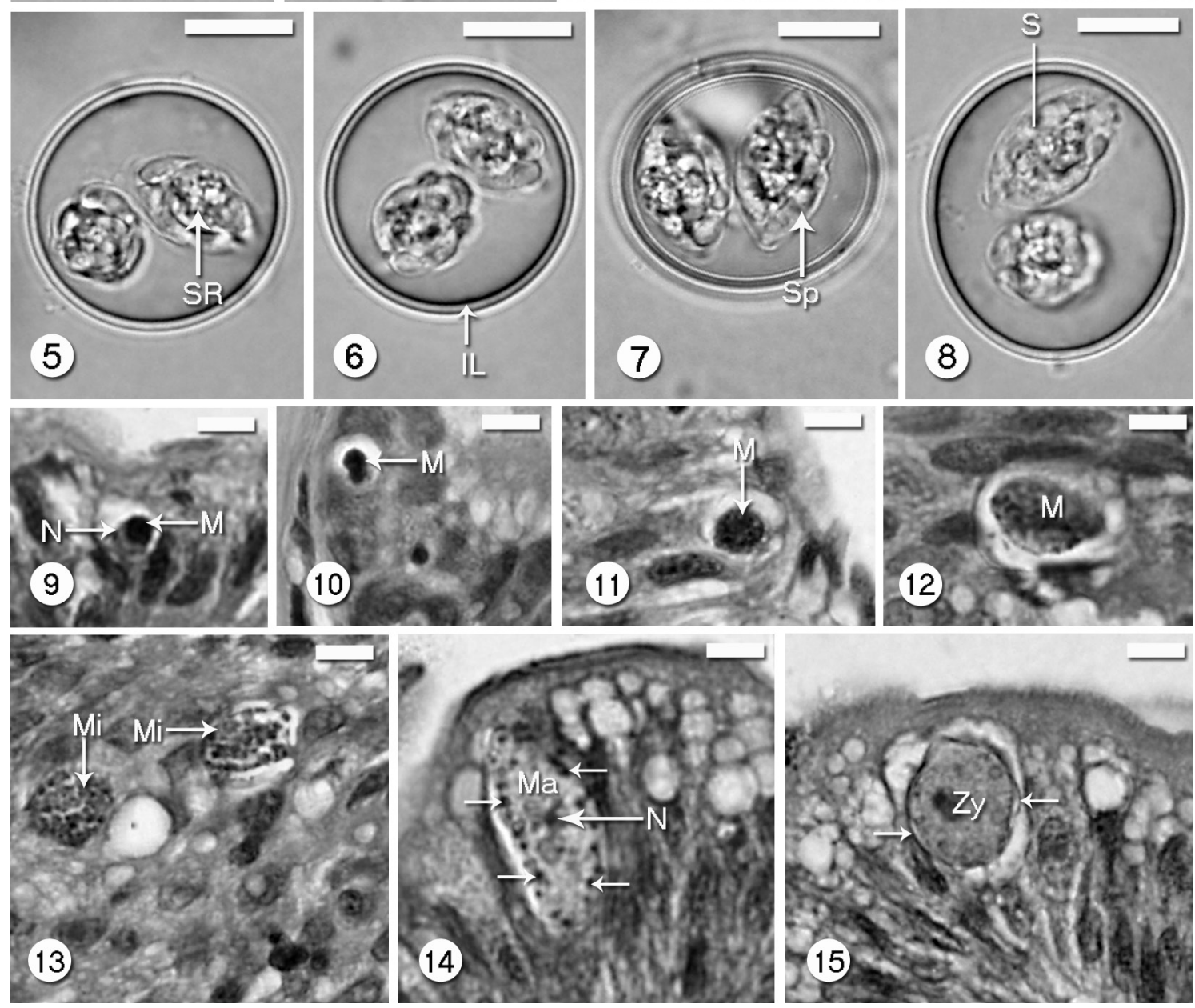

Figs. 1-15. Isospora alyousifi nom. n. from the intestine of Acanthodactylus schmidti. 1-8. Mature oocysts showing the wide size range and steady increase in size from the smaller to the larger oocysts. The oocyst surrounded with the outer layer (OL) and inner layer (IL) membrane, containing two sporocysts (S), each with Stieda body (SB), sporocyst residuum (SR) and four sporozoites (Sp). 9-15. Endogenous development and endogenous stages. 9, 10. Early meronts $(\mathrm{M})$ and nucleus shifted to one pole of enterocytes $(\mathrm{N})$. 11. Developing meront (M). 12. Mature meront (M). 13. Microgamonts (Mi) with a large number of small nuclei. 14. Macrogamonts (Ma) with wall-forming bodies arranged at the periphery (arrows) and a centrally located nucleus (N). 15. Zygote (young oocyst) (Zy) surrounded by thin envelope (arrows). Scale bars: $1-8=10 \mu \mathrm{m}, 9-15=5 \mu \mathrm{m}$. 
Endogenous stages. Observed within nuclei of enterocytes in posterior segment of small intestine. In heavily infected lizards endogenous stages also found in anterior intestine. Nuclei shifted to one pole in infected cells (Figs. 9, 10). As development of endogenous stages progressed, nuclei became gradually consumed and transformed into thin envelope around parasite (Fig. 15). Early trophozoites spherical (Figs. 9, 10), 3-5 in diameter. Developing meronts also spherical, 6-8 in diameter (Fig. 11). Mature meronts subspherical to ovoid, 11-13 $\times 6-8$ (Fig. 12). Microgamonts subspherical, 7-9 × 5-7, distinguished by large number of small nuclei (Fig. 13). Macrogamonts ovoid to elliptical, 18-20 × 6-9, identified by wall-forming bodies arranged at periphery and by centrally located nucleus (Fig. 14). Zygotes (young oocysts) spherical, 12-14 in diameter (Fig. 15).

Type host: Acanthodactylus schmidti Haas.

New material deposited: Photomicrographs and slide with histological sections are deposited at the Zoology Department Museum, College of Science, King Saud University, Riyadh, Saudi Arabia (Coll. No. I/30/2012).

$\mathrm{S}$ p or u 1 a ti on: Exogenous and majority of recovered oocysts became fully sporulated within 12 hours at $\left(25 \pm 1^{\circ} \mathrm{C}\right)$.

Site of infection: Endogenous stages developed within the nuclei of the enterocytes.

Prevalence: $20 \%(8 / 40)$ in the Thomama area $\left(24^{\circ} 41^{\prime} \mathrm{N}\right.$, $\left.46^{\circ} 42^{\prime} \mathrm{E}\right)$ in Riyadh City, Saudi Arabia.

E ty mology: The specific epithet is given in honour of Mohamed Alyousif, who first described the species.

\section{DISCUSSION}

The oocysts of all members of the genus Isospora possess two sporocysts with four sporozoites in each and a single polar Stieda body (Barta et al. 2005). Descriptions of new isosporan species are traditionally based solely on oocyst morphology (e.g., Pellerdy 1974, Upton et al. 2001). In the 1990's, photomicrographic documentation became common (Duszynski 1999). However, this oocyst-based classification has proven problematic. The risk of identifying some eimerian coccidians solely by the morphology of their oocysts and sporocysts have been discussed by numerous authors (see Finkelman and Paperna 1994), and species of Isospora sensu lato are no excep-

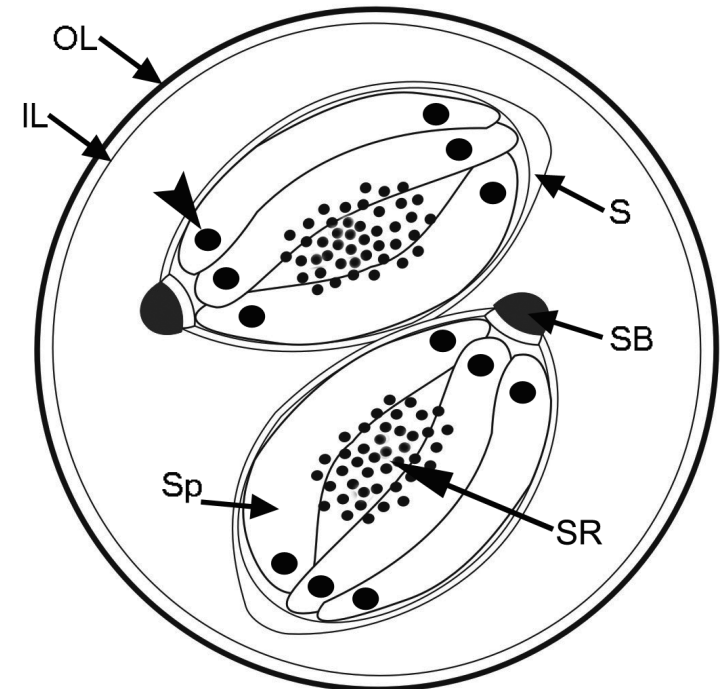

Fig. 16. Schematic drawing of an oocyst of Isospora alyousifi nom. n. The oocyst surrounded by the outer layer (OL) and inner layer (IL) membrane, containing two sporocysts (S), each one with Stieda body (SB), sporocyst residuum (SR) and four sporozoites (Sp); each sporozoite has two refractile bodies (arrowheads). Scale bar $=10 \mu \mathrm{m}$.

tion (Lainson and Paperna 1999). As Berto et al. (2011) have recently argued, reliable classification is dependent on a statistically based evaluation of the morphometrics of the oocysts and, where possible, all the developmental stages of the species life cycle.

It is not uncommon that a species of parasite has been described from just a single infected host (Perkins et al. 2011). In terms of morphology, this small sample size may not permit an adequate examination of the variability present within a species. Thus, if the parasite is encountered again, slight morphological differences may drive investigators to describe it as a new species (Perkins et al. 2011). One set of issues in species identification, therefore, is an over-reliance of oocyst morphology for identification purposes, combined with inadequate sample sizes.

Three species of Isospora have been described from lizards of the genus Acanthodactylus. These species are I. abdallahi Modrý, Koudela et Šlapeta, 1998, I. acanthodactyli Sakran, Fayed, El-Toukhy et Abdel-Gawad, 1994

Table 1. Comparative descriptive measurements (in $\mu \mathrm{m}$ ) of Isospora alyousifi nom. n. with morphologically similar species.

\begin{tabular}{|c|c|c|c|c|c|}
\hline Species/ Reference & Host & Oocyst size & Oocyst shape and SI* & Sporocyst size & Sporocyst shape and SI* \\
\hline $\begin{array}{l}\text { Isospora abdallahi } \\
\text { Modrý, Koudela et Šlapeta, } 1998\end{array}$ & $\begin{array}{l}\text { Acanthodactylus } \\
\text { boskianus }\end{array}$ & $\begin{array}{l}25.8(24.5-29.0) \times \\
23.9(23.0-25.5)\end{array}$ & $\begin{array}{l}\text { Spherical or subspherical } \\
1.07(1.00-1.16)\end{array}$ & $\begin{array}{l}15.4(14-16) \times \\
9.4(9-10)\end{array}$ & $\begin{array}{l}\text { Ovoid } \\
1.60(1.50-1.80)\end{array}$ \\
\hline $\begin{array}{l}\text { Isospora acanthodactyli Sakran, Fa- } \\
\text { yed, El-Toukhy et Abdel-Gawad, } 1994\end{array}$ & $\begin{array}{l}\text { Acanthodactylus } \\
\text { boskianus }\end{array}$ & $\begin{array}{l}17.2(16.4-18.8) \times \\
16.4(15.0-17.2)\end{array}$ & $\begin{array}{l}\text { Spherical } \\
1.02\end{array}$ & $\begin{array}{l}9.3(7.4-10.4) \times \\
5.9(5.0-6.3)\end{array}$ & Ovoid \\
\hline $\begin{array}{l}\text { Isospora acanthodactyli Alyousif et } \\
\text { Al-Shawa, } 1997 \text { (=I. alyousifi) }\end{array}$ & $\begin{array}{l}\text { Acanthodactylus } \\
\text { schmidti }\end{array}$ & $\begin{array}{l}27.9(25.1-29.0) \times \\
25.5(22.7-27.8)\end{array}$ & $\begin{array}{l}\text { Spherical } \\
1.09(1.03-1.30)\end{array}$ & $\begin{array}{l}11.6(11.2-12.6) \times \\
8.0(7.5-8.4)\end{array}$ & $\begin{array}{l}\text { Ovoid } \\
1.32(1.27-1.54)\end{array}$ \\
\hline $\begin{array}{l}\text { Isospora alyousifi nom. n. (present } \\
\text { study) }\end{array}$ & $\begin{array}{l}\text { Acanthodactylus } \\
\text { schmidti }\end{array}$ & $\begin{array}{l}24.6(17.0-29.0) \times \\
21.0(16.0-26.0)\end{array}$ & $\begin{array}{l}\text { Spherical } \\
1.11(1.06-1.20)\end{array}$ & $\begin{array}{l}13.4(8-16) \times \\
8.5(6-10)\end{array}$ & $\begin{array}{l}\text { Ovoid } \\
1.40(1.10-1.70)\end{array}$ \\
\hline
\end{tabular}

*SI: shape index (length/width ratio) 
and I. alyousifi nom. n. (syn. I. acanthodactyli Alyousif et Al-Shawa, 1997) (Table 1). Isospora abdallahi differs in having a thicker oocyst wall and the ranges of measurements of oocysts and sporocysts never overlap those of I. alyousifi. Although I. acanthodactyli looks similar to $I$. alyousifi, its oocyst wall is $2.2-3.8 \mu \mathrm{m}$ thick compared to $1.5 \mu \mathrm{m}$ only in I. alyousifi and the length of their oocysts and sporocysts does not overlap.

Alyousif and Al-Shawa (1997) overlooked the original description of I. acanthodactyli by Sakran et al. (1994) and used the same name for an apparently distinct species, the name of which thus became unavailable as homonym of the former one. A new name, I. alyousifi, is proposed and the species is redescribed based on new material from the same host, with similar size of oocysts and sporocysts, and identical other features as those of I. acanthodactyli Alyousif et Al-Shawa, 1997.

Acknowledgments. The authors extend their appreciation to the Deanship of Scientific Research at King Saud University for funding the work through the research group project number RGP-VPP-004.

\section{REFERENCES}

Alyousif M.S., Al-Shawa Y.R. 1997: Isospora acanthodactyli new species from Acanthodactylus schmidti with a new geographical record for I. deserti from Agama pallida (Finkelman and Paperna, 1994) in Saudi Arabia. Pakistan J. Zool. 29: 219-223.

Barta J.R., Schrenzel M.D., Carreno R., Rideout B.A. 2005: The genus Atoxoplasma (Garnham 1950) as a junior objective synonym of the genus Isospora (Schneider 1881) species infecting birds and resurrection of Cystoisospora (Frenkel 1977) as the correct genus for Isospora species infecting mammals. J. Parasitol. 91: 726-727.

Berto B.P., Luz H.R., Flausino W., Teixeira-Filho W.L., FerReIRA I., Lopes C.W.G. 2011: Isosporoid coccidia (Apicomplexa: Eimeriidae) parasites of tanagers (Passeriformes: Thraupidae) from the Marambaia Island, Brazil. Pesq. Vet. Bras. 31: 798-805.

DUSZYNSKi D.W. 1999: Critical comment: revisiting the code: clarifying name-bearing types for photomicrographs of Protozoa. J. Parasitol. 85: 769-770.

Finkelman S., Paperna I. 1994: The endogenous development of two new species of Isospora (Apicomplexa: Eimeriidae) from skinks. Syst. Parasitol. 27: 227-235.

Harris D.J., ARnold E.N. 2000: Elucidation of the relationships of spiny-footed lizards, Acanthodactylus (Reptilia, Lacertidae) using mitochondrial DNA sequence, with comments on their biogeography and evolution. J. Zool. 252: 351-362.

Harris D.J., Batista V., Carretero M.A. 2003: Assessment of genetic diversity within Acanthodactylus erythrurus (Reptilia: Lacertidae) in Morocco and the Iberian Peninsula using mitochondrial DNA sequence data. Amphibia-Reptilia 25: 227-232.
LAInson R., PAperna I. 1999: Re-descriptions of Isospora ameivae Carini, 1932 in the teiid lizard Ameiva ameiva and Isospora hemidactyli Carini, 1936 in the gecko Hemidactylus mabouia, with particular reference to their endogenous stages. Mem. Inst. Oswaldo Cruz, Rio de Janeiro 94: 459-466.

Levine N.D. 1973: Protozoan Parasites of Domestic Animals and of Man. Burgess Publishing Company, Minneapolis, Minnesota, $406 \mathrm{pp}$.

Modrý D., Koudela B., Šlapeta J. 1998: Isospora abdallahi sp. n. from the lacertid lizard Acanthodactylus boskianus (Sauria: Lacertidae) from Northern Egypt. Folia Parasitol. 45: 14-16.

Pellerdy L.P. 1974. Coccidia and Coccidiosis. Verlag Paul Parey, Berlin and Hamburg, 959 pp.

Perkins L.S., Martinsen E.S., Falk B.G. 2011: Do molecular matter more than morphology? Promises and pitfalls in parasites. Parasitology 138: 1664-1674.

Rifai L., Modrý D., NeČas P., Amr Z.S. 2003: The occurrence of Acanthodactylus hardyi Haas, 1957 in the Hashemite Kingdom of Jordan and notes on its ecology. Zool. Middle East 28: 33-38.

Sakran T.F., Fayed H.M., El-Toukhy A.A., Abdel-Gawad A. 1994: Studies on Eimeria ghaffari sp. nov. and Isospora acanthodactyli sp. nov. naturally infecting the Egyptian lizard Acanthodactylus boskianus. J. Egypt. German Soc. Zool. 15: 255-272.

Upton S.J., Wilson S.C., Norton T.M., Greiner E.C. 2001: A new species of Isospora Schneider, 1881 (Apicomplexa: Eimeriidae) from the Bali (Rothschild's) mynah Leucopsar rothschildi (Passeriformes: Sturnidae), and comments concerning the genera Atoxoplasma Garnham, 1950 and Isospora. Syst. Parasitol. 48: 47-53. 